
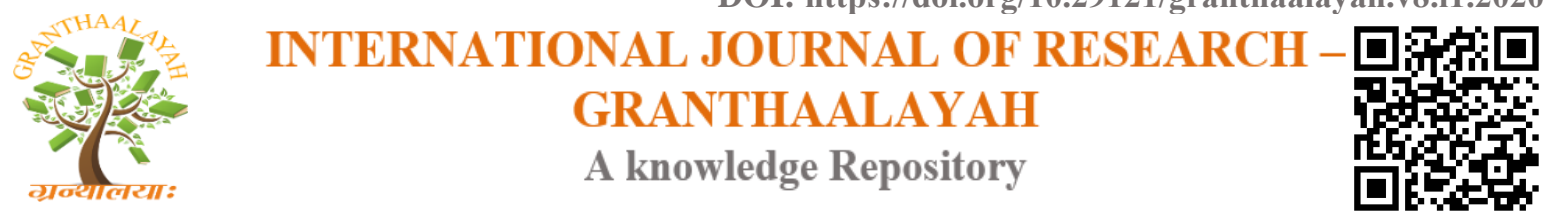

Science

\title{
MINORS ON TRIAL FOR CRIME: VIEW OF THE CHILD PSYCHIATRIST IN JUDICIAL ENVIRONMENT IN BENIN
}

\author{
Anagonou L *1, Houinou Ebo B ${ }^{2}$, Adeossi F ${ }^{3}$, Klikpo E ${ }^{3}$, Salifou S ${ }^{4}$, Gbetogbe K ${ }^{1}$, Gansou \\ $\mathbf{G m}^{3}$, Fiossi Kpadonou $\mathbf{E}^{1}$ \\ ${ }^{1}$ University of Abomey-Calavi, Faculty of Health Sciences, Department of Mental Health, CHU- \\ MEL, Cotonou, Benin \\ ${ }^{2}$ Departmental university hospital center Borgou-Alibori, Parakou, Benin \\ ${ }^{3}$ University of Abomey-Calavi, Faculty of Health Sciences, Department of Mental Health \\ CNHUPC, Cotonou, Benin \\ ${ }^{4}$ University of Lomé, Faculty of Health Sciences, University Clinic of Psychiatry and Medical \\ Psychology, CHU-Sylvanus Olympio, Lomé, Togo
}

\begin{abstract}
The developmental path of the minor may be marked by particular situations such as conflicts with the law, various crimes. The situations, contexts and processes that lead to crime are multiple. Thus, the aim of our research was to study the characteristics of minors judged for crime, seen in a judicial space. This was a retrospective, cross-sectional, descriptive study carried out at the Cotonou First Instance Court. Data were collected from the judicial files of minors tried for crime by the juvenile court ruling on criminal matters from 1 January 2011 to 31 December 2015; 34 files were taken into account. The respondents were all adolescents aged between 10 and 18 years. The majority of them were tried for homicide $(61.7 \%)$ and rape $(32.4 \%)$. For $35.3 \%$ of the minors tried for crime, the relationship with opposite sex parent had poor quality. These minors received a firm prison sentence (88.2\%), and $11.8 \%$ of them were placed in a foster centre without receiving a prison sentence. Crimes committed by minors calls into question our ability to supervise and provide a safe and appropriate framework for the psychological construction of children and adolescents in our society. Measures should be taken in terms of prevention at various levels to reduce the risk of children developing criminal behaviour.
\end{abstract}

Keywords: Minors; Crime; Homicide; Rape; Child Psychiatrist; Benin.

Cite This Article: Anagonou L, Houinou Ebo B, Adeossi F, Klikpo E, Salifou S, Gbetogbe K, Gansou Gm, and Fiossi Kpadonou E. (2020). "MINORS ON TRIAL FOR CRIME: VIEW OF THE CHILD PSYCHIATRIST IN JUDICIAL ENVIRONMENT IN BENIN." International Journal of Research - Granthaalayah, 8(1), 213-220. 


\section{Introduction}

The minor is a person in the process of construction; it is a child or adolescent whose psychic structure has not yet been definitively constructed. During the developmental path of these minors, situations may arise which have a significant meaning and impact, and which give rise to different interpretations. This is the case of conflicts with the law. The confrontation of a minor with the law could seem unpredictable, even more so his or her position as an offence author. It is difficult for society to conceive, imagine or envisage a criminal child. However, the courts hold children and young people responsible for situations that are considered criminal. The situations, contexts and processes that lead to crime are very diverse; a typical profile of the criminal juvenile cannot be extracted from them. The criminal act cannot be reduced at the individuality of the gesture. It is the intersection or condensation of the psychopathological, existential, social and cultural [1]. The aim of our research was to study the characteristics of minors tried for crime, seen in a judicial space.

\section{Material and Method}

The study was descriptive and retrospective. It took place in the Cotonou Court of First Instance.

Subjects under 18 years of age who were tried for a crime by the juvenile court ruling on criminal matters during the period from 1 January 2011 to 31 December 2015 were included in the study; their judicial file must include a social investigation report, a medical-psychiatric expertise report and a report of the hearing. Minors whose files were empty or incomplete and those whose guilt was not proven at the end of the hearing were excluded.

Data were collected from court records. This collection was carried out over three months (1 December 2016 - 28 February 2017). We conducted a review of the session summary reports and the court files recovered from the court archives. The data collection was carried out on the basis of a pre-established data collection form. The data collection form made it possible, to gather information on the family life of the accused minors, the quality of their relationships with peers and adults, to find elements related to the offence committed, and to identify possible factors associated with their life quality. The processing was manual; data were encoded, processed and analyzed using the statistical software SPSS, version 20. The President of the Cotonou Court of First Instance gave his authorization to consult the court files and to use their contents for the purposes of this study. The confidentiality of the data collected was strictly observed.

\section{Results}

From 1 January 2011 to 31 December 2015, we have identified 34 cases of minors judged by the juvenile court ruling on criminal matters in Cotonou, that meet our selection criteria.

\subsection{Description of Target Population}

These minors were judged for offences such as homicide (58.8\%), rape $(29.5 \%)$, theft (5.9\%), voluntary beating with permanent disability in the victim $(2.9 \%)$; one minor committed both rape and homicide $(2.9 \%)$, as reported in Table No.1. 
Table 1: Distribution of minors tried for crime according to type of offence.

\begin{tabular}{|l|l|l|}
\hline & N & $\%$ \\
\hline Homicide & 20 & 58.8 \\
\hline Rape & 10 & 29.5 \\
\hline Theft & 2 & 5.9 \\
\hline Voluntary beating with permanent disability in the victim & 1 & 2.9 \\
\hline Theft + Homicide & 1 & 2.9 \\
\hline Total & $\mathbf{3 4}$ & $\mathbf{1 0 0 . 0}$ \\
\hline
\end{tabular}

The offence was recognized by $67.6 \%$ of minors. Of the minors tried, $88.2 \%$ received a firm prison sentence and $11.8 \%$ were placed in a safeguard center without receiving a prison sentence; $23.5 \%$ should be placed after serving their prison sentence. The socio-demographic characteristics of minors tried for crimes are reported in Table No.2.

Table 2: Distribution of the survey population by age and gender

\begin{tabular}{|l|l|l|}
\hline & $\mathbf{N}$ & $\mathbf{\%}$ \\
\hline Gender of author & & \\
\hline Memale & 5 & 14.7 \\
\hline Vale & 29 & 85.3 \\
\hline Male & & \\
\hline Female & 15 & 44.1 \\
\hline Author's Age & 19 & 55.9 \\
\hline $10-12$ & & \\
\hline $13-15$ & 2 & 5.9 \\
\hline $16-18$ & 15 & 44.1 \\
\hline Age of the victim compared to that of the perpetrator & 17 & 50.0 \\
\hline Not specified & 2 & \\
\hline Younger than the author & 2 & 5.9 \\
\hline Older than the author & 15 & 44.1 \\
\hline Total & 17 & 50.0 \\
\hline & $\mathbf{3 4}$ & $\mathbf{1 0 0 . 0}$ \\
\hline
\end{tabular}

\subsection{Specific Characteristics of the Minors Surveyed}

The school status and educational level of the minors surveyed are reported in Table No.3. 
Table 3: Distribution of minors according to school status and level of education

\begin{tabular}{|l|l|l|}
\hline & N & \% \\
\hline Scolary status & & \\
\hline Not specified & 2 & 5.9 \\
\hline Never attended school & 5 & 14.7 \\
\hline Dropped out of School & 12 & 35.3 \\
\hline Still at school & 15 & 44.1 \\
\hline School level & & \\
\hline Uneducated & 5 & 14.7 \\
\hline Secondary & 12 & 35.3 \\
\hline Primary & 17 & 50.0 \\
\hline Total & $\mathbf{3 4}$ & $\mathbf{1 0 0 . 0}$ \\
\hline
\end{tabular}

The parents' household type, the status of the parental couple, and the quality of the relationship with the opposite-sex parent are described in Table No.4.

Table 4: Distribution of minors surveyed by type of parents' household, status of the parental couple.

\begin{tabular}{|l|l|l|}
\hline & $\mathbf{N}$ & $\%$ \\
\hline Type of parents' household & & \\
\hline Not specified & 9 & 26.5 \\
\hline Polygamy & 10 & 29.4 \\
\hline Monogamy & 15 & 44.1 \\
\hline Status of the parental couple & & \\
\hline Parents living together & 19 & 55.9 \\
\hline Parents divorced & 11 & 32.4 \\
\hline Death of one or both parents & 3 & 8.8 \\
\hline Divorce then death & 1 & 2.9 \\
\hline Quality of the relationship with the opposite-sex parent & & \\
\hline No information & 7 & 20.6 \\
\hline Poor & 12 & 35.3 \\
\hline Good & 15 & 44.1 \\
\hline Total & $\mathbf{3 4}$ & $\mathbf{1 0 0 . 0}$ \\
\hline
\end{tabular}

\subsection{Psychological Characteristics and Background of the Minors Surveyed}

We explored the psychiatric and judicial personal histories of the minors surveyed, as well as their substance use patterns and the existence of anti-social behaviour. These data are reported in Table No.5. 
Table 5: Recapitulation of the respondents' backgrounds

\begin{tabular}{|l|l|l|}
\hline & $\mathrm{N}$ & $\%$ \\
\hline Use of psychoactive substances & & \\
\hline Use of psychoactive substances & 8 & 23.5 \\
\hline No use of psychoactive substances & 26 & 76.5 \\
\hline History of anti-social behavioural patterns & & \\
\hline Existence of anti-social conducts & 5 & 14.7 \\
\hline No antisocial conducts & 29 & 85.3 \\
\hline Psychiatric personal history & & \\
\hline Existence of psychiatric history & 3 & 8.8 \\
\hline No psychiatric history & 31 & 91.2 \\
\hline Personal judicial history & & \\
\hline Existence of personal judicial history & 1 & 2.9 \\
\hline No personal judicial history & 33 & 97.1 \\
\hline Total & $\mathbf{3 4}$ & $\mathbf{1 0 0 . 0}$ \\
\hline
\end{tabular}

\section{Discussion}

Offences qualified as crimes, tried by the juvenile criminal court are more committed by male minors $(85.3 \%)$ and the majority of their victims are female $(55.9 \%)$. This suggests that violence made, are more likely to be committed by males, and acts of violence suffered noticed with girls/women. This prejudice is also reflected in some of the comments made in our society. As an illustration, we could report those often made in front of a young girl who acts with a certain vigour or physical violence. This girl is reproached for acting like a boy; this straightaway, gives the boy attributes of aggressiveness and the girl attributes of gentleness.

The minors judged for crime in our study population were aged between 10 and 18 years. They were, therefore, all adolescents. Adolescents between aged 16 to 18 were those who had committed more offences classified as crimes (50\%) followed by 13-15year olds. Their victims were often older than them (50\%). Indeed, these age groups are periods when the adolescent, because of the challenges of puberty, seeks to detach himself from parental authority, to forge a certain singularity, while being under the influence of various cognitive and morphological changes. All these upheavals that occur during adolescence make it, a potentially violent period for the subject, who will in turn try to put on act, urges that overwhelm him [2]. It is in these "putting on act", sometimes far-reaching on consequences, that certain offences for which they are charged will be committed. Coutanceau et al [3] report that adolescents who commit such offences are aged between 9 and 17 years old, with a peak around 13-14 years old.

More than half $(61.7 \%)$ of the minors were judged for homicide. The prevalence of homicide found in our study is high compared to that found by Zeiller et al [4] in France (9.43\%). This difference is probably due to the fact that the authors had worked on a larger sample than ours. 
Rape $(32.4 \%)$ represented the second category of offence for which minors were tried. This proportion of judiciarized rapes remains high when we know that the vast majority of rapes are still unknown to the judiciary [5]. It should be noted, however, that for some time now in Benin there are several centres for the treatment of different types of violence, including rape. Awareness of the laws punishing violences is constant, as the awareness about procedures and supports offered to victims.

From a psychopathological point of view, the violence perpetrated by the minors in our study population could be explained by the fact that, the affects and impulses are experienced and expressed with extreme or even violent intensity during adolescence [6]. For the latter, the outside world seems to exert on him a pressure that he considers violent and which he may wish to get rid of, by using the same violence and sometimes in the form of acting out.

In Benin, access to education for children has been made easier in recent years, by making school free, first for girls and then for all children. However, despite this measure, half of the minors in our study were either dropped out of school or not attending school. Our results are identical with previous studies on the population of minors in conflict with the law in Benin, which had shown a strong violence predisposition to children who were dropped out of school or not attending school [7]. Mucchielli [8] in his study on youth violence noted that the constant and recurring characteristic of youth, regardless of the type of violence, is the problematic nature of their school careers and situations. Our sample is composed of adolescents; it is easy to understand that schooling levels oscillate between primary and secondary levels.

These results from our study suggest that most of these adolescents experienced difficulties in school at a very early age, which undoubtedly contributed to their falling behind or dropping out of school. This could be an element of disinvestment in schooling in favour of a form of "delinquency" or, on the contrary, it was this early-onset "delinquency" that led to this disinvestment in schooling. Indeed, education can offer several advantages; it leaves little time for the adolescent to have bad company and inappropriate behaviour, when this education is well attended by persons with authority (parents, guardians, educators/teachers). It also allows the adolescent to learn about what is illegal, the risk involved, when breaking the law and thus to avoid certain compromising situations.

The results of our study reveal that most of the minors come from monogamous families $(44.1 \%)$ and their parents were living together at the time of the offence $(55.9 \%)$. These results go against the prejudices conveyed in society, which suggest that adolescents who commit criminal offences come from polygamous, separated families. According to Marcelli and Braconnier [6], the family structure of adolescent perpetrators of violence includes parental couples, dissociated families, single parents or blended families in proportions that do not appear too different from the general population. Beyond the type of household, it is the various deficiencies in family life that truly constitute a risk factor for deviance; $44.1 \%$ of the minors surveyed had divorced or deceased parents.

Our study found that one-third of minors had poor quality relationships with the opposite sex parent. The quality of the relationship between the child and the parents is a determining factor in the child's perception of himself or herself and those around him or her. Relationships marked by 
violence and humiliation could shape an insecure, defensive adolescent. Racicot found that a child who has been a victim of physical violence is at risk of becoming a violent adult, just as an abused teenager is at risk of becoming an abusive adult [9].

Virtually all of the minors in our sample, tried for crime, were on their first encounter with the justice system. Only one of the minors tried for homicide had previously been in trouble with the law, for theft; he had not been prosecuted, the complaint had been settled amicably at the police station. Our results are similar to those of Romero [10]. For all the others, it was their first offence brought to court. Zeiller and Couraud [4] made the same finding that the young offenders had little or no criminal record. On the other hand, in previous study carried out about minors in conflict with the law in foster centre in Benin [11] we found that $67.7 \%$ of minors had a judicial history. It was adolescent in break-up with their families, which are large, polygamous, separated or divorced families, or families affected by the death of one or both parents; they do not have the capacity to provide adequate protection and education for these children.

Approximately one-quarter of the minors on trial used or had used psychoactive substances. The use of psychoactive substances has a disinhibitory effect on brain function. It lowers the threshold of tolerance to frustration, causes irritability and increases impulsivity. As a result, it induces more dangerous behaviour under the influence of these substances [12]. As dangerous as they are for the individual himself, they are just as dangerous for others.

There is a link between alcohol and drug use and violence based on the psychopharmacological model. According to this explanatory model, psychoactive substances act on specific areas of the nervous system where the centres of aggressiveness, impulsiveness and inhibitions are located, thus leading to violent acts on the part of the user [12]. Pham et al [13], in their work, report problems of addiction to psychoactive substances in adolescents who have committed sexual assault.

Among the respondents, we found a previous social behaviour disorders with $14.7 \%$ of them. Antisocial behaviour is to some extent part of the behavioural changes that can occur during adolescence. They are predictive of a later antisocial personality disorder when they persist, repeat and do not change positively despite attempts to readjust them, and may therefore fall within the realm of psychiatry [14].

In our sample, we found the presence of symptoms suggestive of mental illness in $8.8 \%$ of the minors. According to Bourgeois and Benezech [15], "criminological" dangerousness is closely correlated with "psychiatric" dangerousness. Violent behaviour is linked to the presence of proven mental disturbances in the perpetrator. The criminal risk is high when social difficulties are combined with medical and psychological problems.

The offence was recognized by $67.6 \%$ of minors. Of the minors tried, $88.2 \%$ received a firm prison sentence and $11.8 \%$ were placed in a safeguard centre without receiving a prison sentence; $23.5 \%$ should be placed after serving their prison sentence. Sanctions that advocate placements, in fact propose educational measures for minors. During their stay in a protection centre, adolescents are accompanied, supervised and receive vocational training or schooling in the community. These 
accompanying measures, which are alternatives to imprisonment, make it possible to prepare the minor's social reintegration. They also constitute a form of prevention of recidivism.

\section{Conclusion}

The crime committed by a child or adolescent, although difficult to imagine, to conceive of, is perhaps among the least mysterious. This action calls into question our ability to supervise, to offer a safe and appropriate framework for the psychological construction of children and adolescents in our environment, in our society. Measures should be taken in terms of prevention at various levels to reduce the risk of children developing criminal behaviour.

\section{References}

[1] RAOULT P-A. L'agir criminel adolescent. In: Clinique et psychopathologie des agirs. Presses universitaires de Grenoble, 2008; 7-64

[2] BIRAUX A. Adolescence face of society's prejudices. Adolescence, 2012; 80 (2): 297-306

[3] COUTANCEAU R et al. Victimes et auteurs de violence sexuelle. Dunod; 2016; 384p

[4] ZEILLER B et COURAUD S. Criminal children and adolescents: psychopathological aspects. Law and society. 1994; 27: 365-374

[5] Le GOAZIOU V. Rapes at the assizes: a look at on judicial movement. Archives of criminal policy. 2012; 1 (34) 93-101

[6] MARCELLI D, BRACONNIER A. Adolescence et psychopathologie.7ème édition. Paris: Elsevier Masson; 2011, 689p

[7] TROCHU GC, AMAHOUMI J. Rapport sur les conditions de privation de liberté des enfants au Bénin, y compris les violences en détention. Organisation mondiale contre la torture-Enfant solidaire d'Afrique et du monde (OMCT - ESAM), 2011; 9-11

[8] MUCCHIELLI L. L'évolution de la délinquance des mineurs. Agora débats/Jeunesse. 2010; 56(3) $87-101$

[9] RACICOT K et al. Reduce the consequences of the child's exposure to domestic violence. Why focus on the mother-child relationship? International Social Psychology Notebooks. 2012; 86(2): 321-42

[10] ROMERO M. Sexual violence between minors: age and consent at the heart of the judicial debate. Society and youth in difficulty. 2018; 21: 1-21

[11] ANAGONOU et al. Social and familial maladjustment: social representations in closed educational center for teenagers and youth. International journal of research Granthaalayah. 2019; 11(7): 187194

[12] Neuroscience: substance use and addiction. WHO, 2004, 40 p.

[13] PHAM TH, DUCRO C, LEMASSON A-C. Adolescents sex offenders: Aetiological, diagnoses and prognoses characteristics. Medical and psychological anal, psychiatric journal. $2010 ; 6(168)$ :4547

[14] DUMAS JE. Psychopathologie de l'enfant et de l'adolescent. 4ème édition. Bruxelles : de Boeck. 2013; 783p

[15] BOURGEOIS M.L, BENEZECH M. Criminal dangerousness, psychopathology and psychiatry comorbidity. Medical and psychological anal, psychiatric journal. 2001; 7 (159): 475-86.

*Corresponding author.

E-mail address: luccea2@ gmail.com 